\title{
Effects of Somatostatin Analogs and Dopamine Agonists on Insulin-Like Growth Factor 2-Induced Insulin Receptor Isoform A Activation by Gastroenteropancreatic Neuroendocrine Tumor Cells
}

\author{
Roxanne C.S. van Adrichem ${ }^{a}$ Wouter W. de Herder ${ }^{a}$ Kimberly Kamp ${ }^{a}$ \\ Michael P. Brugts ${ }^{a}$ Ronald R. de Krijger ${ }^{b, c}$ Diana M. Sprij-Mooij ${ }^{a}$ \\ Steven W.J. Lamberts ${ }^{a}$ Peter M. van Koetsveld ${ }^{a} \quad$ Joseph A.M.J.L. Janssen ${ }^{a}$ \\ Leo J. Hofland ${ }^{a}$ \\ ${ }^{a}$ Division of Endocrinology, Department of Internal Medicine, and ${ }^{b}$ Department of Pathology, Erasmus Medical \\ Center, Rotterdam, and ${ }^{\mathrm{C}}$ Reinier de Graaf Hospital, Delft, The Netherlands
}

\section{Key Words}

Gastroenteropancreatic neuroendocrine tumors · Insulin-like growth factor 2 - Insulin receptor $A$.

Somatostatin analogs · Dopamine agonists · Human pancreatic neuroendocrine tumor cells

\begin{abstract}
Background: Gastroenteropancreatic neuroendocrine tumors (GEP-NETs) express insulin-like growth factor (IGF)-related factors [IGF1, IGF2; insulin receptor (IR)-A, IR-B; IGFbinding protein (IGFBP) 1-3] as well as somatostatin (SSTRs) and dopamine $D_{2}$ receptors (D2Rs). Objectives: To (1) compare mRNA expression of IGF-related factors in human pancreatic NET (panNET) cell lines with that in human GEP-NETs to evaluate the usefulness of these cells as a model for studying the IGF system in GEP-NETs, (2) determine whether panNET cells produce growth factors that activate IR-A, and (3) investigate whether somatostatin analogs (SSAs) and/or
\end{abstract}

\begin{tabular}{ll}
\hline KARGER & $\begin{array}{l}\text { ( } 2016 \text { The Author(s) } \\
\text { Published by S. Karger AG, Basel } \\
0028-3835 / 16 / 1036-0815 \$ 39.50 / 0\end{array}$ \\
E-Mail karger@karger.com & This article is licensed under the Creative Commons Attribution- \\
www.karger.com/nen & $\begin{array}{l}\text { NonCommercial-NoDerivatives 4.0 International License (CC BY- } \\
\text { NC-ND) (http://www.karger.com/Services/OpenAccessLicense). } \\
\text { Usage and distribution for commercial purposes as well as any dis- } \\
\text { tribution of modified material requires written permission }\end{array}$
\end{tabular}

dopamine agonists (DAs) influence the production of these growth factors. Methods: In panNET cells (BON-1 and QGP-1) and GEP-NETs, mRNA expression of IGF-related factors was measured by quantitative real-time PCR. Effects of the SSAs octreotide and pasireotide (PAS), the DA cabergoline (CAB), and the dopastatin BIM-23A760 (all $100 \mathrm{nM}$ ) were evaluated at the IGF2 mRNA and protein level (by ELISA) and regarding IR-A bioactivity (by kinase receptor activation assay) in panNET cells. Results: panNET cells and GEP-NETs had comparable expression profiles of IGF-related factors. Especially in BON-1 cells, IGF2 and IR-A were most highly expressed. PAS + CAB inhibited IGF2 $(-29.5 \pm 4.9 \%, p<0.01)$ and IGFBP3 $(-20.0 \pm 4.0 \%, p<0.01)$ mRNA expression in BON-1 cells. In BON-1 cells, IGF2 protein secretion was significantly inhibited with BIM-23A760 (-23.7 $\pm 3.8 \%)$. BON-1- but not QGP-1conditioned medium stimulated IR-A bioactivity. In BON-1 cells, IR-A bioactivity was inhibited by BIM-23A760 and PAS $+\mathrm{CAB}(-37.8 \pm 2.1 \%$ and $-30.9 \pm 4.1 \%$, respectively, $\mathrm{p}<$ $0.0001)$. Conclusions: (1) The BON-1 cell line is a representa- 
tive model for studying the IGF system in GEP-NETs, (2) BON1 cells produce growth factors (IGF2) activating IR-A, and (3) combined SSTR and D2R targeting with PAS + CAB and BIM23A760 suppresses IGF2-induced IR-A activation.

(C) 2016 The Author(s)

Published by S. Karger AG, Basel

\section{Introduction}

The insulin-like growth factor (IGF) system is considered to play an important role in gastroenteropancreatic neuroendocrine tumors (GEP-NETs) [1-3]. The IGF system is involved in cell metabolism, growth, differentiation, and survival [4-6]. Known proteins that are part of this IGF system include IGF1 and IGF2, IGF receptor 1 (IGF1R), IGF2R, insulin receptor (IR) isoforms A (IR-A) and $B$ (IR-B), and IGF-binding proteins 1,2 , and 3 (IGFBP1-3).

The tumor-promoting role of IGF1, IGF2, and IGF1R in cancer has previously been explored [7-9]. IGFs can also exert their effects after binding to IR-A and IR-B. IR-A has mainly mitogenic effects and IR-B is involved in metabolic activities $[7,9]$. We have recently shown that, compared to IGF1R and IR-B, IR-A was the most predominantly expressed receptor in GEP-NETs [10]. In addition, we have shown that BON-1 pancreatic NET (panNET) cells produce growth factors (IGF2) that stimulate IGF1R in an autocrine/paracrine manner [11]. To the best of our knowledge, the functional role of IR-A has not been studied in this respect.

GEP-NET cells also express somatostatin receptors (SSTRs) and dopamine type 2 receptors (D2Rs), which are known to inhibit the secretion of many factors/hormones [12-14]. SSTRs and D2Rs are highly, but variably, expressed in most GEP-NETs, and their expression may depend on the stage of tumor dedifferentiation [12-14]. Of the SSTRs, SSTR2 is the most abundantly expressed subtype. Somatostatin analogs (SSAs) such as octreotide (OCT) and lanreotide, which act primarily via SSTR2, are used in the treatment of GEP-NETs and were previously shown to control symptoms related to the overproduction of hormones and bioactive substances, and more recently to control tumor progression as well $[15,16]$.

In theory, targeting SSTRs and/or D2Rs could result in lowering of the production of factors that interact with IR-A. Heterodimerization of SSTRs and D2Rs can result in receptors with an enhanced functional activity $[17,18]$. As such, the combination of single-receptor ligands such as dopamine agonists (DAs) and SSAs, and also somatostatin-dopamine (SS-DA) chimeric compounds, could have synergistic effects by targeting these coexpressed receptors in GEP-NETs. Beneficial effects of chimeric compounds and multiligand SSAs were already shown in a subgroup of patients with NETs and growth hormone/ prolactin-secreting pituitary adenomas [19-22]. In one study, antiproliferative effects were observed in the small intestinal NET (siNET) cell line KRJ-I after incubation with multiligand SSAs but not with SS-DA, because KRJI cells lack D2R expression [23].

To the best of our knowledge, there are no studies in GEP-NET cells in which the effect of targeting SSTRs and D2Rs on the production of IGF-related factors has been evaluated. The main aims of our study were: (1) to compare the expression of the IGF system in human panNET cells (BON-1 and QGP-1) and a series of GEP-NET tissues and to investigate in which aspect the human panNET cell models reflect the human IGF system in GEPNETs; (2) to evaluate whether panNET cells produce growth factors that are able to activate IR-A, and (3) to investigate whether SSAs and/or DAs can influence the production of these growth factors.

\section{Materials and Methods}

\section{Cell Lines and Culture Conditions}

For functional experiments, we used the human panNET cell lines BON-1 and QGP-1. The BON-1 cell line was established from a lymph node metastasis of a human functional panNET [24] and was a kind gift of Dr. C.M. Townsend (The University of Texas Medical Branch, Galveston, Tex., USA). The QGP-1 cell line, which was derived from a pancreatic islet cell carcinoma, was obtained from the Japanese Collection of Research Bioresources (JCRB) Cell Bank [25].

In kinase receptor activation (KIRA) bioassays, we utilized the human embryonic kidney (HEK) cell line Flip-in ${ }^{\mathrm{TM}}-293$ from Invitrogen (Breda, The Netherlands), which was stably transfected with plasmids (pNTK-2) containing a cDNA insert of the human IR-A gene, using Fugene ${ }^{\circledR}$ transfection reagents according to manufacturer's protocol [26]. The IR-A plasmid was kindly provided by Axel Ullrich (Martinsried, Germany).

Cell lines were routinely cultured in $75-\mathrm{cm}^{2}$ cell culture flasks from Corning (Amsterdam, The Netherlands). BON-1 cells were cultured in culture medium consisting of a 1:1 mixture of DMEM and $\mathrm{F}-12 \mathrm{~K}$ medium, supplemented with $10 \%$ fetal bovine serum (FBS), $100 \mathrm{U} / \mathrm{ml}$ penicillin, $0.5 \mathrm{mg} / \mathrm{l}$ Fungizone, and $2 \mathrm{mM} \mathrm{L-glu-}$ tamine. QGP-1 cells were cultured in RPMI 1640 culture medium enriched with $10 \% \mathrm{FBS}$ and $100 \mathrm{U} / \mathrm{ml}$ penicillin. HEK IR-A cells were grown in DMEM containing 10\% FBS, $100 \mathrm{U} / \mathrm{ml}$ penicillin, $100 \mu \mathrm{g} / \mathrm{l}$ streptomycin, and $500 \mu \mathrm{g} / \mathrm{ml}$ geneticin from Invitrogen.

The cell lines were passaged weekly by trypsinization with tryp$\sin /$ EDTA $(0.05 \% / 0.53 \mathrm{~mm})$ and resuspension in medium. Trypan blue staining was used to assess cell viability, which always exceeded $95 \%$. Before plating, cells were counted microscopically in a standard hemocytometer. Periodically, cells were confirmed as free of Mycoplasma. The cell culture conditions in the incubator were kept at a humidified atmosphere of $5 \% \mathrm{CO}_{2}$ at $37^{\circ} \mathrm{C}$. 
Cell Experiments for mRNA Expression and IR-A Bioactivity

(KIRA Assay)

For all mRNA expression and IR-A bioactivity experiments, both panNET cell lines were seeded at a density of 100,000 cells/ well in 12-multiwell culture plates (Corning). After 48 and $72 \mathrm{~h}$, the media were refreshed with serum-free medium.

In order to test whether growth factors produced by panNET cells could influence the tyrosine kinase activity of IR-A, 72-hour conditioned medium of BON-1 cells and QGP-1 cells was collected. Since QGP-1-conditioned medium showed no tyrosine kinase IR-A bioactivity, we did not further evaluate the effects of SSAs/ DAs on this cell line. Therefore, all further experiments were performed with BON-1 cells only.

BON-1 cells were incubated for $72 \mathrm{~h}$ without or with SSAs and/ or DAs at a concentration of $100 \mathrm{nM}$. After $72 \mathrm{~h}$ of incubation, supernatant of the cells was collected, stored at $-20^{\circ} \mathrm{C}$, and later used for IR-A bioassays. The same control and treated BON-1 cells were used for total RNA isolation. The samples were stored at $-20^{\circ} \mathrm{C}$ until analysis. The ability of BON-1-secreted factors to stimulate IR-A phosphorylation was measured using an in-house IR-A KIRA assay according to a previously published method [27]. Bioactivity was expressed relative to a standard curve of insulin. The treatment groups were tested in quadruplicate.

\section{Test Substances}

Regarding SSAs, we tested OCT (Novartis Pharma AG, Basel, Switzerland) and the multi-receptor-binding SSA pasireotide (PAS), also known as SOM230 [28]. PAS was a gift from Novartis. The DA used was cabergoline (CAB; Pharmacia-Pfizer, New York, N.Y., USA). The SS-DA chimeric compound BIM-23A760 was provided by Biomeasure Inc./IPSEN (Milford, Mass., USA). Cells were treated with either single drugs or with drug combinations, namely OCT $+\mathrm{CAB}$ and PAS + CAB. The SSTR and D2R binding affinities of all compounds are listed in online supplementary table 1 (for all online suppl. material, see www.karger.com/doi/10.1159/000444280) [22, 28-33]. Stock solutions of SSAs were prepared in $0.01 \mathrm{M}$ acetic acid and $0.1 \%$ bovine serum albumin. $\mathrm{CAB}$ was dissolved in $70 \%$ ethanol. All stock solutions were aliquoted at concentrations of $10^{-4} \mathrm{M}$ and stored at $-20^{\circ} \mathrm{C}$. For each experiment, fresh working solutions were diluted in serum-free medium.

\section{GEP-NET Tissues}

The diagnosis of GEP-NET was based on both clinical parameters and histology. Samples of GEP-NETs were immediately frozen after surgery in liquid nitrogen and stored at $-80^{\circ} \mathrm{C}$ until further analysis. Tissues obtained from the Erasmus Medical Center (MC) Tissue Bank were stored according to a standardized protocol [34]. Approval from the Medical Ethics Committee of the Erasmus MC, as well as informed consent to use the tumor tissues for research purposes, was obtained.

\section{Quantitative Real-Time PCR}

Total RNA of panNET cells and GEP-NET samples was isolated to determine mRNA expression of the IGF-related factors according to the manufacturer's protocol with a High Pure Isolation KIT (Roche Diagnostics, The Netherlands).

Poly $\mathrm{A}^{+} \mathrm{mRNA}$ isolation for detection of SSTR and D2R mRNA in panNET cells was performed according to a previously used method [35]. The synthesis of cDNA and quantitative real-time PCR was conducted as previously described [36].

SSA and DA Effects on IGF2-Induced IR-A Activation in NET Cells
The used primer probe sets of all IGF-related factors, including their sequences and concentrations, have been previously published [10]. Relative mRNA expression of IGF-related factors was calculated using the comparative threshold method after efficiency correction of target and reference gene (HPRT) transcripts [37, 38 ]. The tested compounds did not significantly change the expression of HPRT after $72 \mathrm{~h}$ of incubation (data not shown).

\section{IGF2 Protein Assay}

To test whether inhibition of IR-A activation could be clarified by modulation of IGF2 secretion, we used a 'two-step' sandwichtype immunoassay with a Non-Extraction IGF-II Enzyme-Linked Immunosorbent Assay Kit (DSL Germany GMBH-Benelux, Assendelft, The Netherlands). The assay was performed according to the protocol supplied by the manufacturer. The intra- and interassay coefficients of variability were 5.2 and $6.9 \%$, respectively.

\section{IGF2 Immunohistochemistry}

Expression of the IGF2 protein in GEP-NET tissues was measured by immunohistochemistry (IHC) using a polyclonal goat antibody (1:500; Santa Cruz Biotechnology, Dallas, Tex., USA) as previously described [36]. The immunoreactivity of IGF2-stained GEP-NET tissues was interpreted in a semiquantitative manner and expressed as an immunoreactivity score (IRS) between 0 and 6 [39]. The IGF2 staining and IRS counting procedure were done by 2 independent researchers, and any discrepancy was resolved by consensus review.

\section{Statistical Analysis}

For statistical analysis, GraphPad Prism ${ }^{\circledR}$ version 6.04 (GraphPad Software, San Diego, Calif., USA) was used. Comparative statistical evaluations between groups were accomplished with unpaired t tests and one-way ANOVA followed by Tukey's tests for multiple post hoc comparisons. Correlation analysis was performed using Spearman's rank correlation tests. Each drug condition of an experiment was tested in quadruplicate, with the exception of the IGF2 ELISA, which was done in triplicate. All experiments were carried out at least 2 times and gave comparable results. Outliers were excluded by Grubbs' test with the GraphPad QuickCalcs outlier calculator. Data are reported as means \pm SEM. In all analyses, a two-sided $\mathrm{p}$ value $<0.05\left({ }^{*} \mathrm{p}<0.05,{ }^{* *} \mathrm{p}<0.01\right)$ was considered statistically significant.

\section{Results}

\section{Levels of $m R N A$ Expression of SSTRs and D2Rs in panNET Cells}

Figure 1a shows mRNA levels of SSTRs and D2Rs in BON-1 cells. The SSTR subtypes were expressed in the following order: SSTR5 $>$ SSTR1 $>$ SSTR2 $>$ SSTR3 $(0.57$ $\pm 0.093,0.47 \pm 0.058,0.081 \pm 0.011$, and $0.036 \pm 0.0065$ ). The D2R mRNA expression level was $0.27 \pm 0.011$. Of all receptors, SSTR5 was expressed most highly.

In QGP-1 cells, the order of expression was the same as in BON-1 cells, but the expression of SSTR3 was not detectable (SSTR5: $0.05 \pm$ 0.02; SSTR1: $0.038 \pm 0.022$; 
Fig. 1. mRNA expression profiles of SSTRs and $\mathrm{D} 2 \mathrm{R}(\mathbf{a}, \mathbf{b})$ and IGF-related factors (c, d) in BON-1 (a, c) and QGP-1 cells (b, d), expressed as relative expression normalized to HPRT. For all samples: $n=2$. $\mathrm{ND}=$ Not detectable.

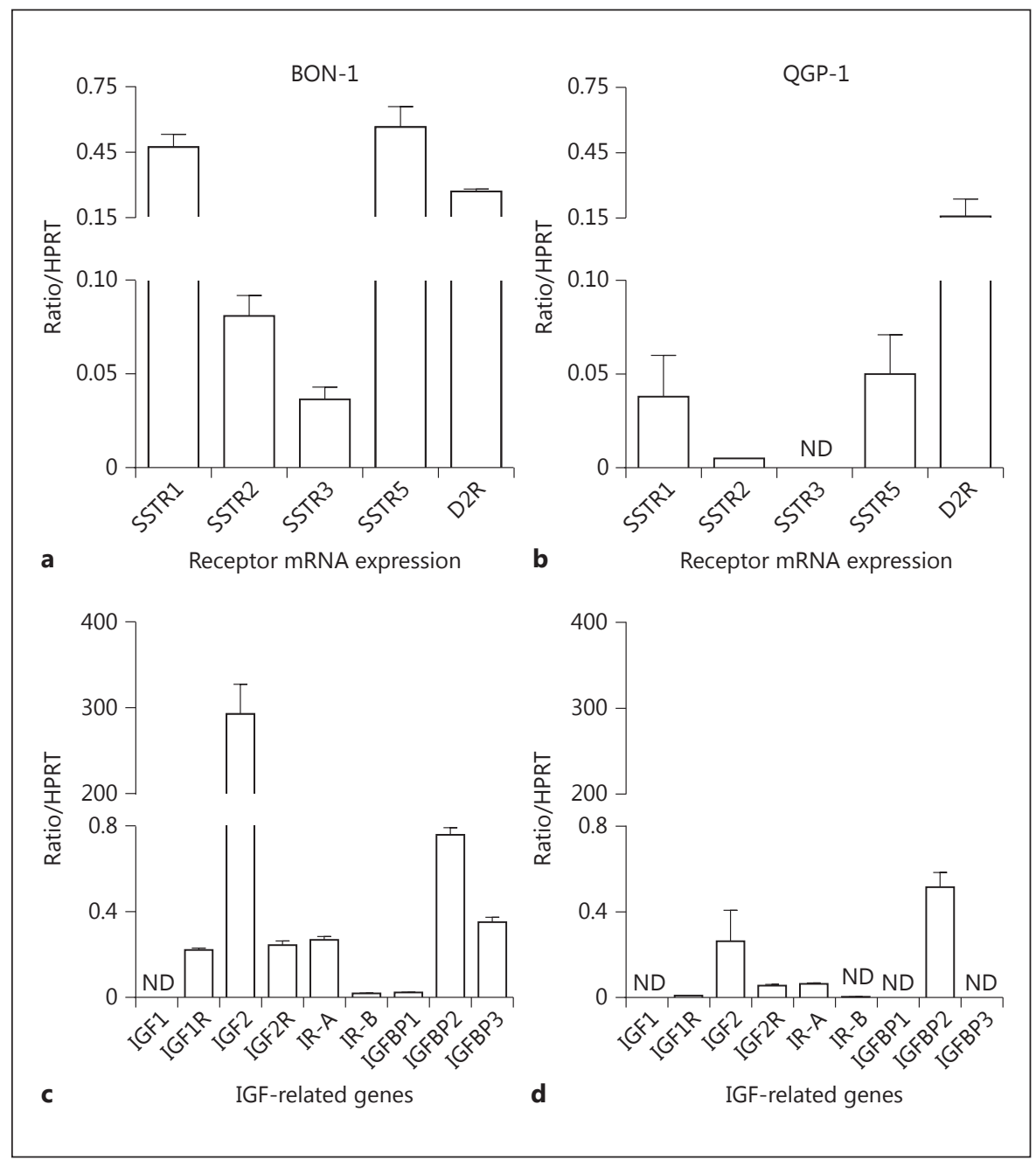

SSTR2: $0.005 \pm$ 0; SSTR3: not detectable). D2R is the most highly expressed receptor in QGP-1 cells, and is expressed at the same level as in BON-1 cells $(0.16 \pm 0.08)$ (fig. 1b).

\section{mRNA Expression of IGF-Related Factors in panNET Cells}

mRNA expression levels of the IGF-related factors were measured in BON-1 (fig. 1c) and QGP-1 cells (fig. 1d). The results are expressed as relative expression (normalized to HPRT). In BON-1 cells, IGF2 was expressed at the highest level $(292.8 \pm 34.60)$. BON-1 cells expressed statistically significantly higher mRNA levels of IGF2 than of IGF1 ( $p<0.01)$. Of the IGF-related receptors, IR-A had the highest mRNA expression level ( 0.27 $\pm 0.016)$. IR-A was significantly more highly expressed (14.3-fold) than IR-B (0.27 \pm 0.016 vs. $0.019 \pm 0.0016, \mathrm{p}<$
$0.01)$. In addition, IR-A was expressed at a higher level (1.2-fold) than IGF1R ( $0.27 \pm 0.016$ vs. $0.22 \pm 0.0093$, $\mathrm{p}<$ $0.05)$. No statistically significant difference in mRNA expression levels was observed between IR-A and IGF2R $(0.27 \pm 0.016$ vs. $0.24 \pm 0.019, p>0.05)$ or between IGF1R and IGF2R $(0.22 \pm 0.0093$ vs. $0.24 \pm 0.019, \mathrm{p}>0.05)$. With respect to IGFBPs, IGFBP2 $(0.76 \pm 0.034)$ was expressed at the highest level, followed by IGFBP3 $(0.35 \pm 0.023)$ and IGFBP1 $(0.023 \pm 0.0019)$.

IGF-related factors were expressed in a relatively comparable pattern in QGP-1 cells, but their expression levels were considerably lower than in BON-1 cells. panNET IGF2 $(292.8 \pm 34.60$ vs. $0.26 \pm 0.15, \mathrm{p}=0.01)$ and IR-A $(0.27 \pm 0.016$ vs. $0.064 \pm 0.005, p=0.0003)$ were significantly more highly expressed in $\mathrm{BON}-1$ cells than in QGP-1 cells. In addition, in QGP-1 cells there was no detectable expression of IGFBP1 and IGFBP3. 
Fig. 2. mRNA expression patterns of IGFrelated receptors $(\mathbf{a}, \mathbf{b})$ and proteins $(\mathbf{c}, \mathbf{d})$ in siNETs $(\mathbf{a}, \mathbf{c} ; \mathrm{n}=18)$ and panNETs $(\mathbf{b}, \mathbf{d}$; $\mathrm{n}=7$ ), expressed as log relative expression normalized to HPRT. Horizontal bars represent means.

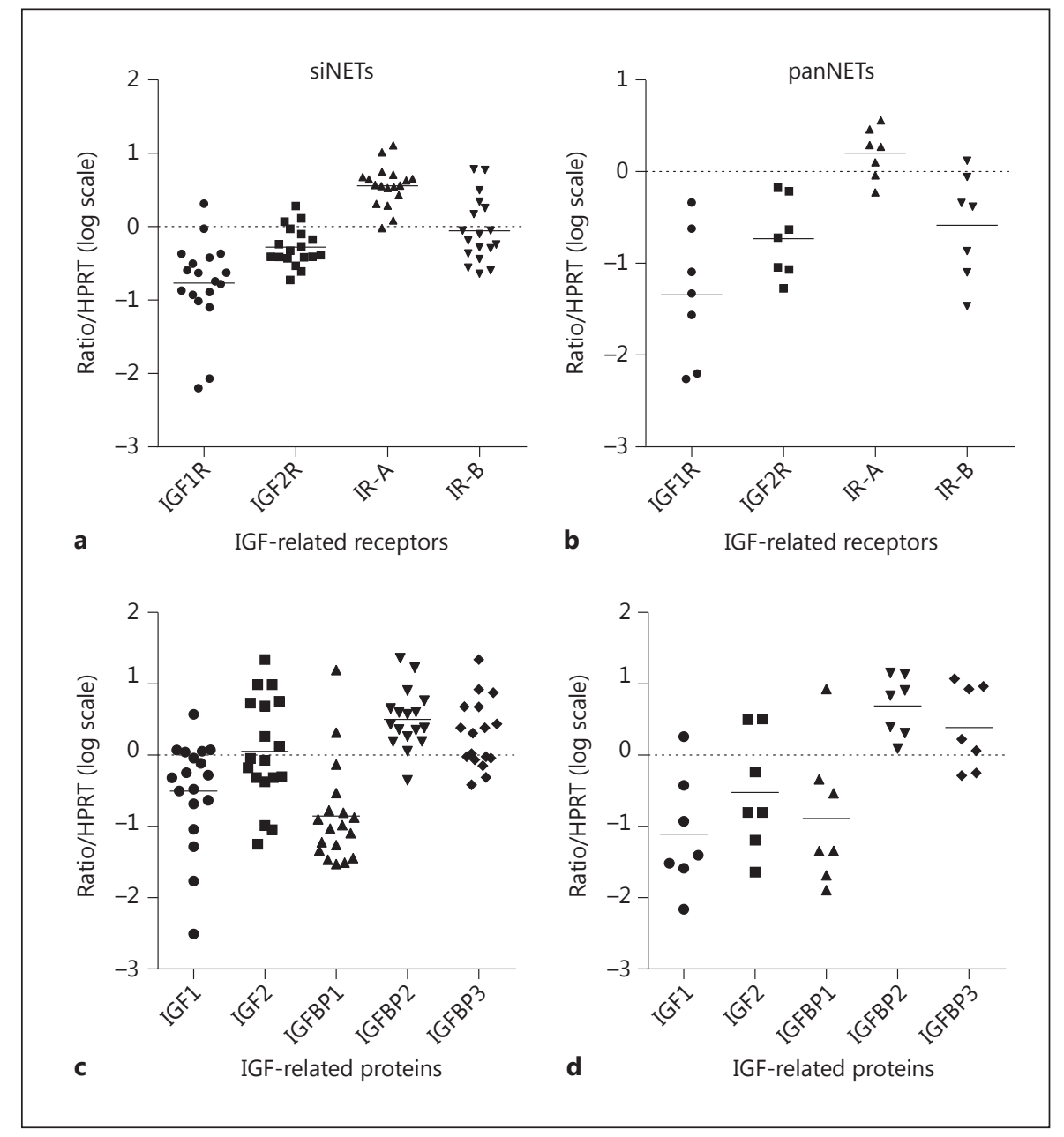

mRNA Expression of IGF-Related Factors in

GEP-NET Tissues

The mRNA expression levels of IGF-related factors were investigated in primary human GEP-NETs originating from the small intestine ( $\mathrm{n}=18$; fig. 2a: IGF-related receptors, fig. 2c: IGF-related proteins) and pancreas ( $\mathrm{n}=7$; fig. 2b: IGF-related receptors, fig. 2d: IGF-related proteins). Expression data on a subset of these GEP-NETs were previously reported [10]. All genes were expressed in highly variable amounts. Of the IGFs, IGF2 was most highly expressed (siNET: $3.60 \pm 1.31$; panNET: $1.05 \pm 0.56$ ). IGF2 was expressed at a higher level than IGF1 (siNET: $3.60 \pm 1.31$ vs. $0.71 \pm 0.20$; panNET: $1.05 \pm 0.56$ vs. $0.35 \pm 0.25$ ). IR-A was the most prominently expressed IGF-related receptor in this series of GEP-NET tissues; it was expressed at a higher level than IR-B (siNET: $4.34 \pm 0.69$ vs. $1.50 \pm 0.42$; panNET: $1.87 \pm 0.41$ vs. $0.47 \pm 0.18$ ) and IGF1R as well (siNET: 0.34 \pm 0.11; panNET: $0.12 \pm 0.06$ ) (fig. 2a, b). Although the ex- pression levels varied, overall siNETs and panNETs showed mRNA expression patterns of IGF-related factors comparable to those of the panNET cell lines. Results of logarithmic gene expression levels are shown.

\section{Receptor Bioactivity after Stimulation with}

\section{Serum-Free Conditioned BON-1 Cell Medium}

Conditioned medium of BON-1 cells stimulated IR-A bioactivity, whereas control, unconditioned medium did not (fig. 3a). Conditioned medium of QGP-1 cells did not show any detectable bioactivity of IR-A (data not shown).

In the IR-A KIRA assay, the strongest inhibition of BON-1 conditioned medium-induced IR-A bioactivity was observed after treatment for $72 \mathrm{~h}$ with the SS-DA chimera BIM-23A760 $(-37.8 \pm 2.1 \%, \mathrm{p}<0.0001)$. Other compounds or combinations of compounds (all tested at $100 \mathrm{nM}$ ) that induced a statistically significant decrease in conditioned medium-induced IR-A bioactivity were: 


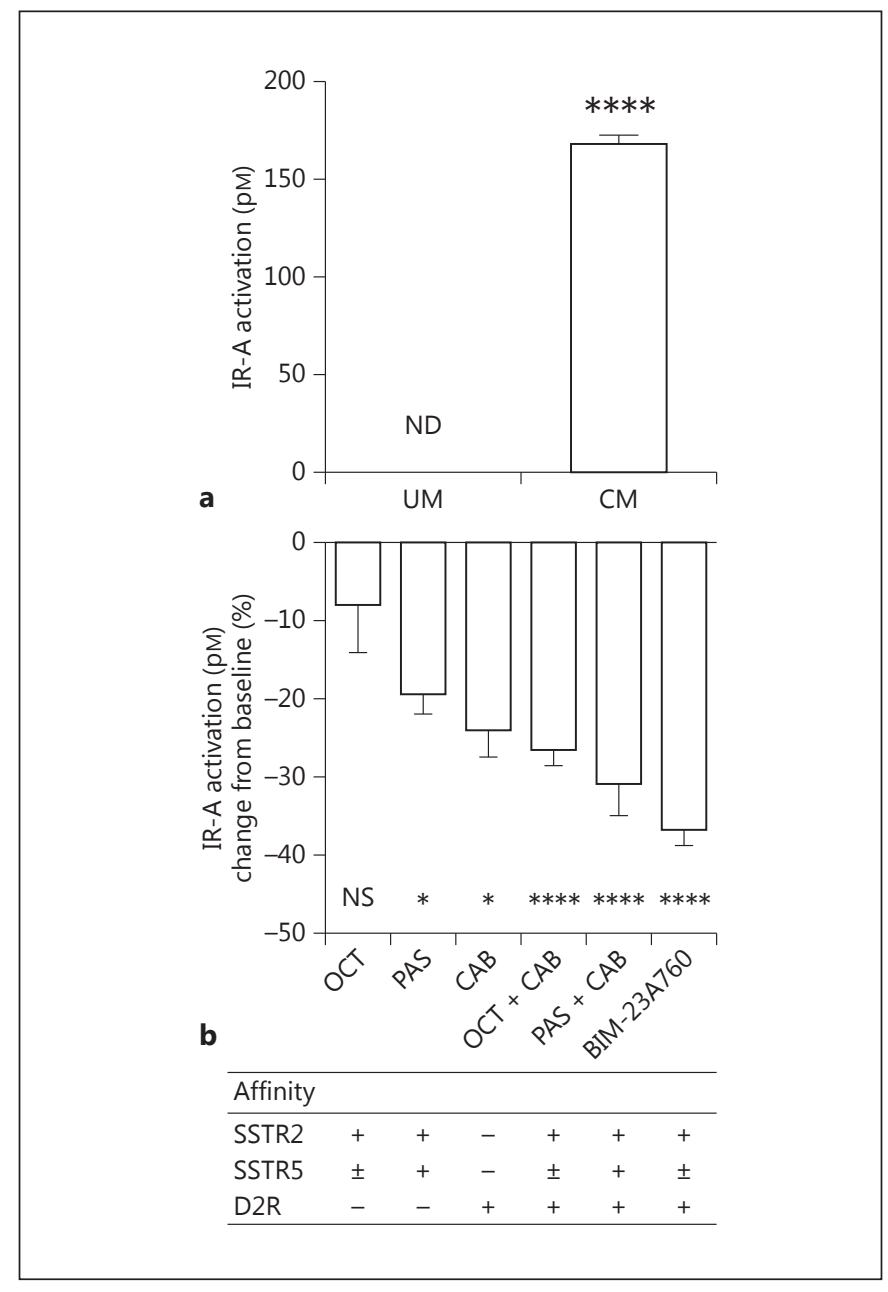

Fig. 3. a IR-A bioactivity of unconditioned BON-1 cell medium (UM) and supernatant of conditioned BON-1 cell medium (CM). $\mathrm{ND}=$ Not detectable. $\mathbf{b}$ IR-A bioactivity after treatment with single or combinations of compounds (all at concentrations of $100 \mathrm{nM}$ ), expressed as percentage change from baseline. ${ }^{*} \mathrm{p}<0.05,{ }^{* * * *} \mathrm{p}<$ 0.0001 vs. control.

$\mathrm{PAS}+\mathrm{CAB}(-30.9 \pm 4.1 \%, \mathrm{p}<0.0001), \mathrm{OCT}+\mathrm{CAB}$ $(-26.5 \pm 2.1 \%, \mathrm{p}<0.01), \mathrm{CAB}(-24.1 \pm 3.4 \%, \mathrm{p}<0.05)$, and PAS $(-19.4 \pm 2.6 \%, \mathrm{p}<0.05)$. No statistically significant differences in IR-A bioactivity were observed after treatment with OCT $(-8.0 \pm 6.1 \%)$. Data, expressed as percentage change from baseline of IR-A activation, are shown in figure $3 \mathrm{~b}$. None of the compounds had a direct effect on IR-A phosphorylation (data not shown), indicating that the effects involved inhibition of the secretion of growth factors produced by $\mathrm{BON}-1$ cells. Under the conditions that we used, concentrations of IGF2 between 0.25 and $0.5 \mathrm{nM}$ induced an IR-A activation comparable to that of $\mathrm{BON}-1$ conditioned medium (data not shown).

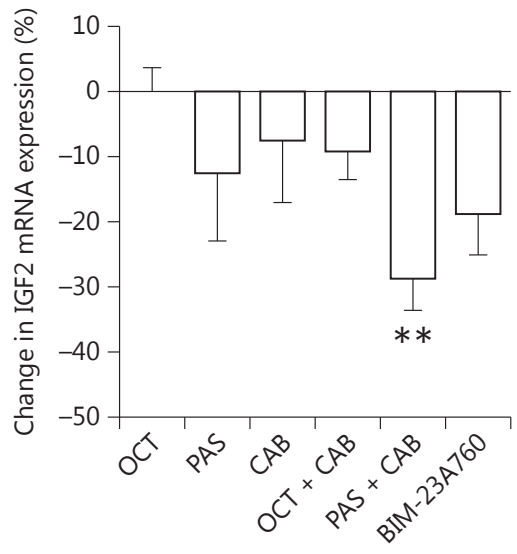

Fig. 4. Change in mRNA expression of IGF2 after $72 \mathrm{~h}$ of treatment with single or combinations of compounds in BON-1 cells. ${ }^{* *} \mathrm{p}<$ 0.01 vs. control.

mRNA Levels of IGF-Related Factors after Treatment with SSAs and DAs

First, mRNA levels of IGF-related factors were measured after 6, 24, and $72 \mathrm{~h}$ of treatment. After $72 \mathrm{~h}$, the mRNA data showed the most significant changes. Therefore, all experiments were accomplished at that time point. A significant decrease in IGF2 mRNA was observed after treatment with PAS + CAB $(-29.5 \pm$ $4.9 \%, \mathrm{p}<0.01)$. The results are shown in figure 4 . IGFBP3 expression as well was significantly decreased after treatment with PAS + CAB $(-20.0 \pm 4.0 \%, \mathrm{p}<0.01$; data not shown). No other statistically significant effects on mRNA expression were found for the remaining IGF-related factors. None of the other drugs or combinations were able to modulate mRNA expression levels.

\section{IGF2 ELISA}

Total IGF2 protein levels were quantitatively measured in conditioned medium of BON-1 cells. A significant decrease in IGF2 protein levels was observed after 72 $\mathrm{h}$ of incubation with BIM-23A760 (-23.7 $\pm 3.8 \%)$. Inhibitory but statistically nonsignificant effects were observed with the other compounds (OCT: $-12.5 \pm 5.3 \%$; CAB: $-12.1 \pm 4.8 \%$; PAS + CAB: $-9.8 \pm 8.2 \%$; PAS: $-12.0 \pm 3.3 \%$; OCT + CAB: $-5.7 \pm 12.4 \%)$. The results are shown in figure 5 . 


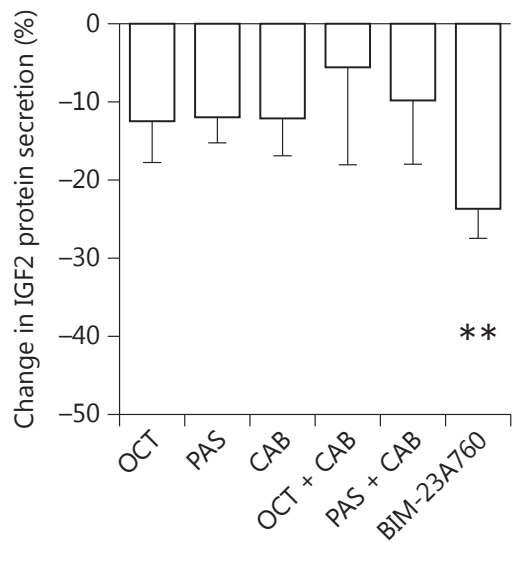

Fig. 5. Change in IGF2 protein secretion in BON-1 cells after $72 \mathrm{~h}$ of treatment with single or combinations of compounds. ${ }^{* *} \mathrm{p}<$ 0.01 vs. control.

\section{IGF2 Immunohistochemistry}

IGF2 IHC was determined in 25 tissue samples of siNET $(n=18)$ and panNET $(n=7)$ in order to examine IGF2 protein expression. Most of the tumors expressed a significant amount of IGF2 protein, although its expression was variable. The intensity and proportion of IGF2 IHC staining were heterogeneous in most of the GEPNET tissues. In online supplementary table 2, the IGF2 mRNA and protein expression levels of both siNETs and panNETs are listed. No significant correlation was observed between IGF2 mRNA and IGF2 protein in siNETs $(\rho=0.17, \mathrm{p}=0.49)$ and panNETs $(\rho=0.44, \mathrm{p}=0.33)$, expressed as IGF2 IRS. Figure 6 shows exemplary photomicrographs of staining of IGF2 in GEP-NET samples with an IRS of 2, 4, and 6, respectively. There was no statistically significant association between the proliferation marker Ki-67 and IGF2 IRS in siNETs $(\rho=-0.09, \mathrm{p}=$ $0.79)$ and panNETs $(\rho=0.89, \mathrm{p}=0.11)$.

\section{Discussion}

To the best of our knowledge, this is the first study having gathered evidence that the human $\mathrm{BON}-1$ cell line is a model that reflects in many respects the typical characteristics of the IGF system in human GEP-NETs. We showed that especially IGF2 and IR-A were expressed at

SSA and DA Effects on IGF2-Induced IR-A Activation in NET Cells high levels in our series of GEP-NETs as well as in the BON-1 cell model. In addition, we demonstrated that SSAs and DAs modulate the secretion of growth factors (e.g. IGF2) produced by BON-1 cells that are capable of activating IR-A.

We measured mRNA levels of IGF-related factors (IGF1, IGF2, IGF1R, IGF2R, IR-A, IR-B, and IGFBP1-3) in both panNET cell lines and GEP-NETs. In earlier publications, the expression of these genes has been studied in human NETs $[2,10]$. However, the quantitative expression of factors of the IGF system, and modulation of the expression of these growth factors (both at the mRNA and the protein level, during treatment with SSAs, DAs, or their combinations), have not been studied so far.

Overall, BON-1 and QGP-1 cells displayed an expression pattern of IGF-related factors which was relatively comparable to that of GEP-NETs, both siNETs and panNETs. However, BON-1 cells did not express detectable levels of IGF1, and QGP-1 cells did not express detectable levels of IGF1, IGFBP1, and IGFBP3. In BON-1 cells, IGF2 mRNA levels were expressed 1,000-fold more highly, and IR-A levels 5-fold more highly, than in QGP-1 cells. The relatively low mRNA expression levels of IGF2 (and IR-A) in QGP-1 cells may explain the absence of effects of conditioned medium of QGP-1 on IR-A bioactivity. Therefore, the QGP-1 cell line appears not to be a suitable model for investigating whether SSAs and/or DAs can modulate the production of these growth factors. On the other hand, both cell lines are panNET cell lines, and the difference between the cell lines might reflect the heterogeneity of this tumor group.

In both BON-1 and QGP-1 cells, we observed higher mRNA expression levels for SSTR1 than for SSTR2. The siNET cell line KRJ-I demonstrated equal mRNA expression levels for SSTR1 and SSTR2 [3]. In most studies where the quantitative mRNA expression levels of SSTRs were studied, SSTR2 was more highly expressed than SSTR1 [40-44]. In general, there is a predominant expression of SSTR1 and SSTR 2 mRNA in NETs, with highly variable mRNA expression levels $[40,45]$. We suggest that these differential findings again represent the heterogeneity of these tumors. No SSTR/D2R mRNA expression levels were determined in our series of GEP-NETs, since expression profiles of these receptors have already been extensively investigated [40,42].

For all experiments, we used the concentration of 100 $\mathrm{nM}$ of OCT, PAS, CAB, and/or BIM-23A760. With this supraphysiological concentration, we expected to observe effects that could answer our primary research question, i.e. to investigate whether the different SSAs 


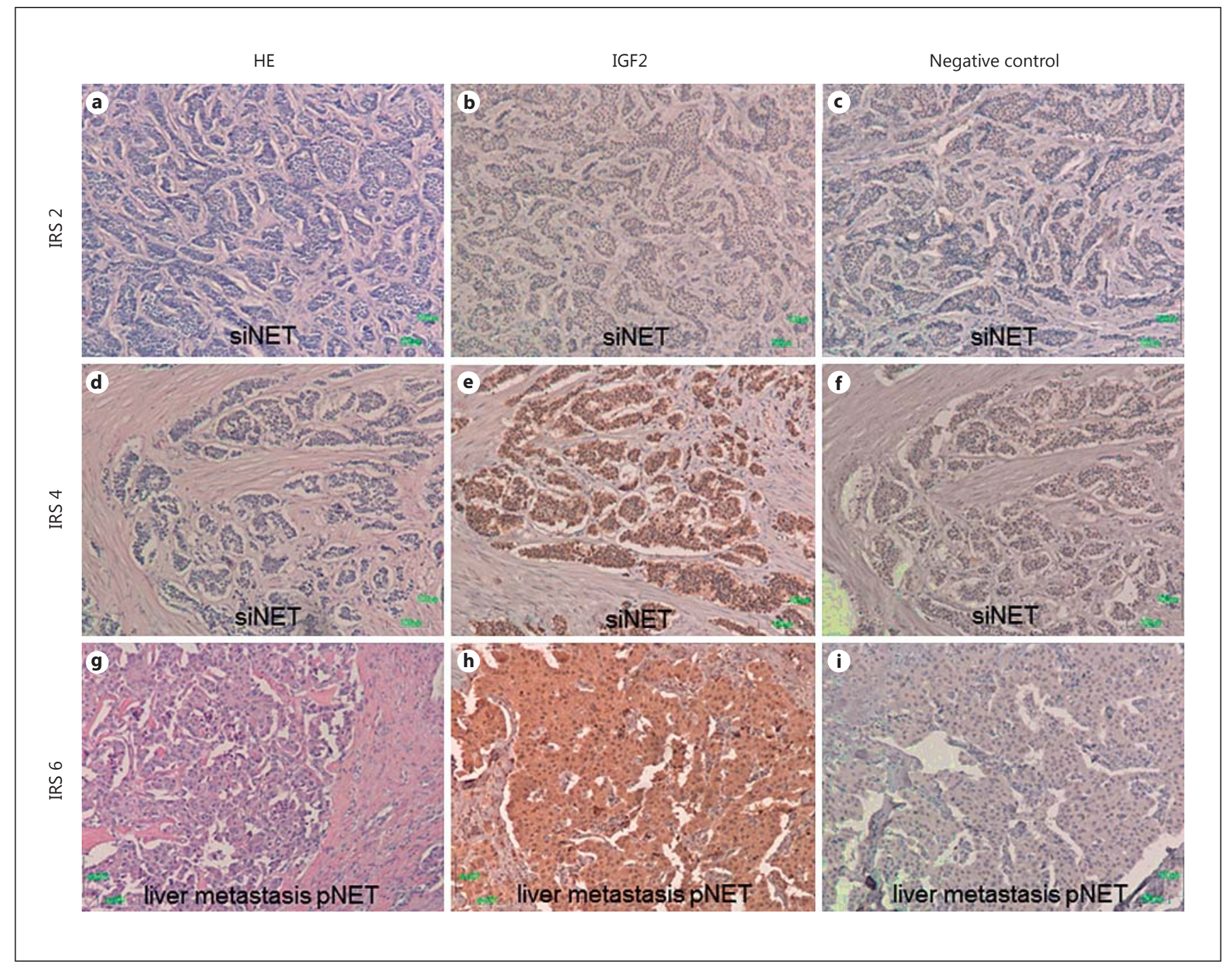

Fig. 6. Exemplary cases of IGF2 IRSs of GEP-NET tissues. a-f siNETs $(n=18)$. $\mathbf{g}-\mathbf{i}$ panNETs $(n=7)$. a, $\mathbf{d}, \mathbf{g}$ HE. b, e, h IGF2. c, f, i Negative controls.

and/or DAs used were able to activate SSTR subtypes and $\mathrm{D} 2 \mathrm{R}$ resulting in a maximal biological response. At such a concentration, it is not fully possible to make statements about the specific involvement of individual SSTR subtypes in this context.

In a previous study, modulation of the IGF2/IGF1R autocrine loop was demonstrated in $\mathrm{BON}-1$ cells using neutralizing IGF2 antibodies [27]. To assess the IGF2mediated activity of IR-A, we used an IR-A KIRA bioassay developed in-house. In the current study, we focused on IR-A bioactivity, as stimulation of IR-A by IGF2 may play a role in signal transduction in tumorigenesis $[7,9]$. With the IR-A bioassay, we found that stimulation of the phosphorylation of tyrosine residues of IR-A by conditioned medium of BON-1 cells was as potent as stimulation with 167 pM recombinant human insulin. As indicated above, a significant IR-A bioactivity of conditioned medium of QGP-1 cells was not observed. This may be explained by the reduced IGF2 mRNA expression in QGP-1 cells, which was approximately 1,000-fold lower than in BON-1 cells.

Since BON-1 cells only produce IGF2 but not IGF1, the most likely explanation for the observed IR-A activation in BON-1 cells is the production of IGF2. After $72 \mathrm{~h}$ of incubation, BON-1 cells treated with PAS $+\mathrm{CAB}$ showed a significant decrease in IGF2 mRNA, while no 
effects were observed on mRNA expression after incubation with any of the other components. PAS and $\mathrm{CAB}$ monotherapy had less effect on mRNA expression. There was only a borderline reduction in IGF2 mRNA after treatment with BIM-23A760. Although SSTR1 was the most highly expressed SSTR subtype in our BON-1 cell line, a 72-hour incubation of BON-1 cells with BIM23926 (SSTR1 analog) did not result in a statistically significant change in IGF2 mRNA expression compared to untreated BON-1 cells $(+113.80 \pm 19.31 \%, \mathrm{p}=0.52)$ [unpubl. data]. Apparently, targeting SSTR1 is not effective in modulating IGF2 mRNA levels. Overall, these results suggest that the SSTR subtypes 2 and 5 and D2Rs may play a role in modulating IGF2 mRNA levels.

BIM-23A760 treatment resulted in a significant decrease in secreted IGF2, while no effect was seen after any of the other treatments. Treatment with PAS + CAB or BIM-23A760 induced a significant decrease in IR-A bioactivity. In the IR-A KIRA bioassay, all compounds or combinations, except OCT, were able to suppress the activation of IR-A. This result indicates that BON-1 conditioned medium-induced IR-A activation can be modified by the (combined) activation of D2R and SSTR subtypes 2 and 5. The absence of an effect of OCT may be explained by the very low SSTR2 expression in BON-1 cells.

While IGF2 expression has previously been demonstrated in GEP-NET tissue at the mRNA level, there are no large studies that have evaluated IGF2 protein expression. In order to study whether IGF2 is also highly expressed in GEP-NET tissues, we performed IHC. The GEP-NET tumors also expressed IGF2 protein at a significant but variable level. Protein expression of SSTRs has already previously been examined in GEP-NET cells [46]. No significant correlations were observed by IHC between IGF2 mRNA expression and IGF2 protein positivity in GEP-NET tissues. Nonetheless, our study sug- gests that IGF2 is expressed at significant levels in almost all GEP-NETs. No significant association between IGF2 IRS and Ki-67 index was found as well, which may be explained by the small sample size of our GEP-NET series.

Although the BON-1 and QGP-1 cell lines are both originating from panNETs, discrepancies in results of experiments between the panNET cell lines indicate that these cell lines represent two different tumor subtypes, namely tumors with a low IGF2 production and panNETs with high levels of IGF2 secretion.

In conclusion, the human BON-1 panNET cell line, and to a lesser extent the QGP-1 cell line, appears to be a suitable model for studying the role of the IGF system in human panNETs. Of all the IGF-related factors, IGF2 and IR-A seem the most important players in human BON-1 panNET cells and human GEP-NETs. We found that most GEP-NET tissues express IGF2 protein as well. In our hands, therapies with the combination of PAS $+\mathrm{CAB}$ or with the SS-DA chimeric compound BIM-23A760, which act through D2R and SSTR subtypes 2 and 5, showed especially inhibitory effects on autocrine/paracrine (IGF2)-induced IR-A activation. Our study suggests that combinations of SSAs and DAs and/or chimeric SS-DA ligands are treatment options showing promise for the treatment of GEP-NETs, and they should be in the focus of future research.

\section{Acknowledgements}

We thank the Erasmus MC Tissue Bank for providing the panNET tumor tissues.

\section{Disclosure Statement}

The authors have nothing to disclose.

\section{References}

1 Hopfner M, Baradari V, Huether A, Schofl C, Scherubl H: The insulin-like growth factor receptor 1 is a promising target for novel treatment approaches in neuroendocrine gastrointestinal tumours. Endocr Relat Cancer 2006; 13:135-149.

-2 Wulbrand U, Remmert G, Zofel P, Wied M, Arnold R, Fehmann HC: mRNA expression patterns of insulin-like growth factor system components in human neuroendocrine tumours. Eur J Clin Invest 2000;30:729-739.
Kidd M, Schally AV, Pfragner R, Malfertheiner MV, Modlin IM: Inhibition of proliferation of small intestinal and bronchopulmonary neuroendocrine cell lines by using peptide analogs targeting receptors. Cancer 2008; 112:1404-1414.

4 Gao J, Chang YS, Jallal B, Viner J: Targeting the insulin-like growth factor axis for the development of novel therapeutics in oncology. Cancer Res 2012;72:3-12.
5 Pollak M: The insulin and insulin-like growth factor receptor family in neoplasia: an update. Nat Rev Cancer 2012;12:159-169.

-6 Ricort JM: Insulin-like growth factor binding protein (IGFBP) signalling. Growth Horm IGF Res 2004;14:277-286.

7 Belfiore A, Frasca F, Pandini G, Sciacca L, Vigneri R: Insulin receptor isoforms and insulin receptor/insulin-like growth factor receptor hybrids in physiology and disease. Endocr Rev 2009;30:586-623.
SSA and DA Effects on IGF2-Induced IR-A Activation in NET Cells
Neuroendocrinology 2016;103:815-825 DOI: $10.1159 / 000444280$ 
8 Rosenzweig SA, Atreya HS: Defining the pathway to insulin-like growth factor system targeting in cancer. Biochem Pharmacol 2010;80:1115-1124.

-9 Samani AA, Yakar S, LeRoith D, Brodt P: The role of the igf system in cancer growth and metastasis: Overview and recent insights. Endocr Rev 2007;28:20-47.

10 van Adrichem RC, Hofland LJ, Feelders RA, De Martino MC, van Koetsveld PM, van Eijck $\mathrm{CH}$, de Krijger RR, Sprij-Mooij DM, Janssen JA, de Herder WW: Chromogranin A, Ki-67 index and IGF-related genes in patients with neuroendocrine tumors. Endocr Connect 2013;2:172-177.

11 Afargan M, Janson ET, Gelerman G, Rosenfeld R, Ziv O, Karpov O, Wolf A, Bracha M, Shohat D, Liapakis G, Gilon C, Hoffman A, Stephensky D, Oberg K: Novel long-acting somatostatin analog with endocrine selectivity: potent suppression of growth hormone but not of insulin. Endocrinology 2001;142:477486.

12 Diakatou E, Kaltsas G, Tzivras M, Kanakis G, Papaliodi E, Kontogeorgos G: Somatostatin and dopamine receptor profile of gastroenteropancreatic neuroendocrine tumors: an immunohistochemical study. Endocr Pathol 2011;22:24-30.

13 Gatto F, Hofland LJ: The role of somatostatin and dopamine $\mathrm{D}_{2}$ receptors in endocrine tumors. Endocr Relat Cancer 2011;18:R233R251.

-14 Srirajaskanthan R, Watkins J, Marelli L, Khan $\mathrm{K}$, Caplin ME: Expression of somatostatin and dopamine 2 receptors in neuroendocrine tumours and the potential role for new biotherapies. Neuroendocrinology 2009;89:308314.

15 Caplin ME, Pavel M, Cwikla JB, Phan AT, Raderer M, Sedlackova E, Cadiot G, Wolin EM, Capdevila J, Wall L, Rindi G, Langley A, Martinez S, Blumberg J, Ruszniewski P; CLARINET Investigators: Lanreotide in metastatic enteropancreatic neuroendocrine tumors. $\mathrm{N}$ Engl J Med 2014;371:224-233.

-16 Rinke A, Muller HH, Schade-Brittinger C, Klose KJ, Barth P, Wied M, Mayer C, Aminossadati B, Pape UF, Blaker M, Harder J, Arnold C, Gress T, Arnold R; PROMID Study Group: Placebo-controlled, double-blind, prospective, randomized study on the effect of octreotide LAR in the control of tumor growth in patients with metastatic neuroendocrine midgut tumors: a report from the PROMID study group. J Clin Oncol 2009;27:46564663.

17 Rocheville M, Lange DC, Kumar U, Patel SC, Patel RC, Patel YC: Receptors for dopamine and somatostatin: formation of hetero-oligomers with enhanced functional activity. Science 2000;288:154-157.

$\checkmark 18$ Rocheville M, Lange DC, Kumar U, Sasi R, Patel RC, Patel YC: Subtypes of the somatostatin receptor assemble as functional homo- and heterodimers. J Biol Chem 2000; 275:7862-7869.
19 Kvols LK, Oberg KE, O’Dorisio TM, Mohideen P, de Herder WW, Arnold R, Hu K, Zhang Y, Hughes G, Anthony L, Wiedenmann B: Pasireotide (SOM230) shows efficacy and tolerability in the treatment of patients with advanced neuroendocrine tumors refractory or resistant to octreotide LAR: results from a phase II study. Endocr Relat Cancer 2012;19:657-666.

20 van der Hoek J, de Herder WW, Feelders RA, van der Lely AJ, Uitterlinden P, Boerlin V, Bruns C, Poon KW, Lewis I, Weckbecker G, Krahnke T, Hofland LJ, Lamberts SW: A single-dose comparison of the acute effects between the new somatostatin analog SOM230 and octreotide in acromegalic patients. J Clin Endocrinol Metab 2004;89:638-645.

21 van der Hoek J, van der Lelij AJ, Feelders RA, de Herder WW, Uitterlinden P, Poon KW, Boerlin V, Lewis I, Krahnke T, Hofland LJ, Lamberts SW: The somatostatin analogue SOM230, compared with octreotide, induces differential effects in several metabolic pathways in acromegalic patients. Clin Endocrinol (Oxf) 2005;63:176-184.

22 Zitzmann K, Andersen S, Vlotides G, Spottl G, Zhang S, Datta R, Culler M, Goke B, Auernhammer CJ: The novel somatostatin receptor 2/dopamine type 2 receptor chimeric compound BIM-23A758 decreases the viability of human GOT1 midgut carcinoid cells. Neuroendocrinology 2013;98:128-136.

23 Kidd M, Drozdov I, Joseph R, Pfragner R, Culler M, Modlin I: Differential cytotoxicity of novel somatostatin and dopamine chimeric compounds on bronchopulmonary and small intestinal neuroendocrine tumor cell lines. Cancer 2008;113:690-700.

-24 Evers BM, Ishizuka J, Townsend CM Jr, Thompson JC: The human carcinoid cell line, BON. A model system for the study of carcinoid tumors. Ann NY Acad Sci 1994;733: 393-406.

25 Iguchi $\mathrm{H}$, Hayashi I, Kono A: A somatostatinsecreting cell line established from a human pancreatic islet cell carcinoma (somatostatinoma): release experiment and immunohistochemical study. Cancer Res 1990;50:36913693.

26 Varewijck AJ, Brugts MP, Frystyk J, Goudzwaard JA, Uitterlinden P, Waaijers AM, Feng Y, Dimitrov DS, Lamberts SW, Hofland LJ, Janssen JA: Circulating insulin-like growth factors may contribute substantially to insulin receptor isoform $\mathrm{A}$ and insulin receptor isoform B signalling. Mol Cell Endocrinol 2013; 365:17-24.

27 Chen JW, Ledet T, Orskov H, Jessen N, Lund S, Whittaker J, De Meyts P, Larsen MB, Christiansen JS, Frystyk J: A highly sensitive and specific assay for determination of IGF-I bioactivity in human serum. Am J Physiol Endocrinol Metab 2003;284:E1149-E1155.
28 Bruns C, Lewis I, Briner U, Meno-Tetang G, Weckbecker G: SOM230: A novel somatostatin peptidomimetic with broad somatotropin release inhibiting factor (SRIF) receptor binding and a unique antisecretory profile. Eur J Endocrinol 2002;146:707-716.

29 De Martino MC, Hofland LJ, Lamberts SW: Somatostatin and somatostatin receptors: from basic concepts to clinical applications. Prog Brain Res 2010;182:255-280.

30 Gerlach M, Double K, Arzberger T, Leblhuber F, Tatschner T, Riederer P: Dopamine receptor agonists in current clinical use: comparative dopamine receptor binding profiles defined in the human striatum. J Neural Transm 2003;110:1119-1127.

- 31 Saveanu A, Gunz G, Guillen S, Dufour H, Culler MD, Jaquet P: Somatostatin and dopamine-somatostatin multiple ligands directed towards somatostatin and dopamine receptors in pituitary adenomas. Neuroendocrinology 2006;83:258-263.

-32 Zatelli MC, Piccin D, Tagliati F, Bottoni A, Ambrosio MR, Margutti A, Scanarini M, Bondanelli M, Culler MD, degli Uberti EC: Dopamine receptor subtype 2 and somatostatin receptor subtype 5 expression influences somatostatin analogs effects on human somatotroph pituitary adenomas in vitro. J Mol Endocrinol 2005;35:333-341.

- 33 Zatelli MC, Tagliati F, Piccin D, Taylor JE, Culler MD, Bondanelli M, degli Uberti EC: Somatostatin receptor subtype 1-selective activation reduces cell growth and calcitonin secretion in a human medullary thyroid carcinoma cell line. Biochem Biophys Res Commun 2002;297:828-834.

- 34 Mager SR, Oomen MH, Morente MM, Ratcliffe C, Knox K, Kerr DJ, Pezzella F, Riegman $\mathrm{PH}$ : Standard operating procedure for the collection of fresh frozen tissue samples. Eur J Cancer 2007;43:828-834.

35 de Bruin C, Pereira AM, Feelders RA, Romijn JA, Roelfsema F, Sprij-Mooij DM, van Aken MO, van der Lelij AJ, de Herder WW, Lamberts SW, Hofland LJ: Coexpression of dopamine and somatostatin receptor subtypes in corticotroph adenomas. J Clin Endocrinol Metab 2009;94:1118-1124.

- 36 De Martino MC, van Koetsveld PM, Feelders RA, Sprij-Mooij D, Waaijers M, Lamberts SW, de Herder WW, Colao A, Pivonello R, Hofland LJ: The role of mTOR inhibitors in the inhibition of growth and cortisol secretion in human adrenocortical carcinoma cells. Endocr Relat Cancer 2012;19:351-364.

37 Pfaffl MW: A new mathematical model for relative quantification in real-time RT-PCR. Nucleic Acids Res 2001;29:e45.

38 Schmittgen TD, Livak KJ: Analyzing realtime PCR data by the comparative $\mathrm{C}_{\mathrm{T}}$ method. Nat Protoc 2008;3:1101-1108.

-39 Noh WC, Kim YH, Kim MS, Koh JS, Kim HA, Moon NM, Paik NS: Activation of the mtor signaling pathway in breast cancer and its correlation with the clinicopathologic variables. Breast Cancer Res Treat 2008;110:477-483. 
40 O'Toole D, Saveanu A, Couvelard A, Gunz G, Enjalbert A, Jaquet P, Ruszniewski P, Barlier A: The analysis of quantitative expression of somatostatin and dopamine receptors in gastro-entero-pancreatic tumours opens new therapeutic strategies. Eur J Endocrinol 2006; 155:849-857.

41 Kanakis G, Grimelius L, Spathis A, Tringidou R, Rassidakis GZ, Oberg K, Kaltsas G, Tsolakis AV: Expression of somatostatin receptors 1-5 and dopamine receptor 2 in lung carcinoids: implications for a therapeutic role. Neuroendocrinology 2015;101:211-222.

- 42 Saveanu A, Muresan M, De Micco C, Taieb D, Germanetti AL, Sebag F, Henry JF, Brunaud L, Enjalbert A, Weryha G, Barlier A: Expression of somatostatin receptors, dopamine $\mathrm{D}_{2}$ receptors, noradrenaline transporters, and vesicular monoamine transporters in 52 pheochromocytomas and paragangliomas. Endocr Relat Cancer 2011;18:287-300.
43 van Hoek M, Hofland LJ, de Rijke YB, van Nederveen FH, de Krijger RR, van Koetsveld PM, Lamberts SW, van der Lely AJ, de Herder WW, Feelders RA: Effects of somatostatin analogs on a growth hormone-releasing hormone secreting bronchial carcinoid, in vivo and in vitro studies. J Clin Endocrinol Metab 2009;94:428-433.

44 Li SC, Martijn C, Cui T, Essaghir A, Luque RM, Demoulin JB, Castano JP, Oberg K, Giandomenico V: The somatostatin analogue octreotide inhibits growth of small intestine neuroendocrine tumour cells. PLoS One 2012; 7:e48411.

45 de Herder WW, Hofland LJ, van der Lely AJ, Lamberts SW: Peptide receptors in gut endocrine tumours. Baillieres Clin Gastroenterol 1996; 10:571-587.

46 Van Buren G 2nd, Rashid A, Yang AD, Abdalla EK, Gray MJ, Liu W, Somcio R, Fan F, Camp ER, Yao JC, Ellis LM: The development and characterization of a human midgut carcinoid cell line. Clin Cancer Res 2007;13: 4704-4712.
47 Hofland LJ, van der Hoek J, van Koetsveld PM, de Herder WW, Waaijers M, Sprij-Mooij D, Bruns C, Weckbecker G, Feelders R, van der Lely AJ, Beckers A, Lamberts SW: The novel somatostatin analog SOM230 is a potent inhibitor of hormone release by growth hormone- and prolactin-secreting pituitary adenomas in vitro. J Clin Endocrinol Metab 2004;89:1577-1585.

48 Jaquet P, Gunz G, Saveanu A, Dufour H, Taylor J, Dong J, Kim S, Moreau JP, Enjalbert A, Culler MD: Efficacy of chimeric molecules directed towards multiple somatostatin and dopamine receptors on inhibition of $\mathrm{GH}$ and prolactin secretion from $\mathrm{GH}$-secreting pituitary adenomas classified as partially responsive to somatostatin analog therapy. Eur J Endocrinol 2005; 153:135-141.

49 Kvernmo T, Hartter S, Burger E: A review of the receptor-binding and pharmacokinetic properties of dopamine agonists. Clin Ther 2006;28:1065-1078. 